\title{
Evaluation of Some Mango Strains under Ismailia Governorate Condition
}

\author{
H. A. Abd El-Kareem, Nehad M. Ahmed and S. I. Habashy \\ Tropical Fruit Research Department, Horticulture Research \\ Institute, Agricultural Research Centre, Cairo, Egypt.
}

\begin{abstract}
7 HIS INVESTIGATION was carried out during the two 1 successive seasons (2012 and 2013) on fourteen mango strains grown at Motreb Zahran orchard, Abu Sultan, Ismailia Governorate Egypt A.R.E. The studied trees were 16-year-old grown in sandy soil and irrigated with drip irrigation system. Flowering date, malformation percentage, date of fruit maturity, tree productivity and fruit quality were studied. Only three strains seem to be promising S9,S10 and S11) which they gave highest values of(productivity per tree, fruit weight, percentage of pulp weight and values of T.S.S. and lowest percentage of malformed panicles, seed weight and acidity. The evaluation indicated that, the strains as superiority can be arranged in a descending order as follows: S9, S11 and S10 may be recommended as a new superior mango cultivars.
\end{abstract}

Keywords: Mongo, Evaluation, Flowering, Productivity, Fruit composition, Fruit quality, Set percentage.

Mango (Mangifera indica L.) belongs to family Anacardiaceae is regarded as the most desired fruit in tropical and sub-tropical regions of the world (Anonymous, 2007 and Shafqat et al., 2012) Mango is consumed mainly as a fresh fruit or as a juice. Its nutritional value is great and is considered one of the richest sources of vitamins, mineral salts, enough amounts of carbohydrates, proteins (Abouraya et al., 2011). There are many factors that influence yield, maturity and quality of fruits, the same cultivar can attains different characteristics in different growing condition. Even in the same region, different environmental conditions at different years can affect quality and maturity of the fruit (Devilliers, 1998). Mango world wide are generally poor, ranging from 4 to 9 ton/ha. in the major production countries (Oosthuyse, 1993).This attributable to wide tree spacing malformation, alternate bearing, environmental factors and fruit drop (Jana and Sharangi,1998). In Egypt, the area of mango orchards reached 130000 fed. in 2009 year producing about 534434 metric tons of fruit. Many cultivars are grown in Egypt facing many problems in productivity, Improving yield and quality of mango cvs. can be enhancing through breeding, selection and better cultural practices (Said and El-Masry 1992, Mou et al., 2009, Sayed et al., 2009, ElAgmey 2010 and El-Kosary et al., 2011).There is present the seedling tree however, to make some of them more desirable than others must propagated by budding or grafting to become a true to type horticultural variety (Nafees et al., 2010). Moreover, mango fruit is increasingly becoming well established as an 
item of international trade (Singh \& Chadha,1981, Mitra et al., 2001 and Mauca et al., 2009).

This investigation aimed to evaluate some seedling tree to assess some attributes and fruit physical, chemical properties of fourteen mango strains grown under Ismailia Governorate conditions to select the promising ones.

\section{Materials and Methods}

This investigation was carried out during two successive seasons (2012 and 2013) on fourteen mango seedling trees grown at Motreb Zahren orchard in Abu Sultan, Ismailia Governorate, Egypt. The observed trees were 16-year-old grown in sandy soil at 6 meters apart and subjected to the normal horticultural practices.

Data were recorded during the two seasons of investigation as follow Flowering behaviour:

In both studied seasons date of flower bud burst and total number of panicles, also malformed inflorcences per tree was counted after full bloom and the percentage of malformed panicles was estimated as follow:

$$
\text { Malformation }(\%)=\frac{\text { number of malformed panicles }}{\text { Total number of panicles }} \times 100
$$

Maturity date and tree yield

Days required to fruit maturity, also number of fruit per tree was recorded, and then yield per tree was calculated as $\mathrm{Kg}$.

Yield tree $=\underline{\text { Average fruit weight }(\mathrm{g}) \mathrm{X} \text { number of fruit/tree }}$

$$
1000
$$

Fruit physical characteristics

At harvest date, samples of nine mango fruits (divided in 3replicates) from each strain were collected randomly and the following properties were examined:

- Peel and pulp colour by using colour chart.

- Peel thickness.

- Pulp content of fiber

- Embryo types (mono or polyembryonic)

Fruit weight, dimensions and shape index

- Fruit weight (g.)

- Fruit length $(\mathrm{cm}$.

- Fruit diameter (cm.)

- Fruit width (cm.)

- Fruit shape index (fruit length/fruit diameter).

Seed, peel and pulp percentage

At ripening (seed, peel and pulp percentage) weight were recorded then there percentage of fruit were estimated as follow:-

Egypt. J. Hort. Vol. 43, No. 1 (2016) 
- Seed $(\%)=$ Seed weight $\times 100$

Fruit weight

- Peel $(\%)=\underline{\text { Peel weight }} \times 100$

Fruit weight

- Pulp $(\%)=$ Pulp weight $\times 100$

Fruit weight

Chemical fruit characteristics:

Total soluble solids (T.S.S) of mango fruit juice were examined by using hand refractometer.

Titratable acidity was determined (as citric acid) according to (A.O.A.C. 1985).

(T.S.S/acid ratio) was also calculated.

Statistical analysis and comparison among means were made by using L.S.D test at 5\% level according to Steel and Torrie (1985).

\section{Results and Discussion}

Date of flowering, number panicles and malformation (\%)

The obtained data in Table 1 revealed that, flowering of four strains (S6, S3, S4 and S1) were earlier started at the period from $22^{\text {nd }}$ to $28^{\text {th }}$ of February and only two strains (S2 and S7) started flowering at $7^{\text {th }}$ and $8^{\text {th }}$ March, while S5 form $4^{\text {th }}$ to $7^{\text {th }}$ April, other strains (S8 to S14) flowering at the period from $20^{\text {th }}$ to $28^{\text {th }}$ April during the two study seasons.

Average number of panicles per tree for (S8) recorded lowest values (86\&87) while, the highest (231\&237) for (S2) ones during first and second seasons respectively, the other strains achieved values between them.

Number of malformed panicles per tree was fluctuant from 4 to 13 in both seasons. Concerning, malformation percentage the proportion ranged around 2.04 to $12.90 \%$ where highest ratio for S5, the other strains that malformed panicles percentages among them.

These results are agreement with finding of Said and El-Masry (1992), Boshra et al. (2007), Serry (2010), El-Agmey (2010) and Nafees et al. (2010) who reported that, all mango strains differed in date of full bloom and malformation is considered to be the most fatal disorders which not only negatively affect plant health but reduces yield.

Harvest date and yield

The harvest date ( as average) during two study seasons as shown in Table 2 where five strains fruits were harvest during July, i.e., S6, S4, S1, S3 and S5 
respectively while, S2 and S7 at first August, the other strains were harvest in period from 16 to 30 September gradually as follows S14, S9, S13, S12, S11, S10 and S8. Regarding the period from full bloom to maturity stage, through study to find out all fruits of strains required about 145 to 156 days.

As for number of fruits per tree differed significantly between the strains where S2 attained the highest fruit numbers (254\&263) while, the lowest numbers (74\&71) attributed S8 in the first and second seasons respectively, the other strains among them. On the other hand, yield as $\mathrm{Kg}$ per tree reached highest quantum for strains 9,10 and 11 those (138.67 \&143.31), (93.29 $\& 109.06)$ and $(91.94 \& 100.98)$ while, the lowest $(20.33 \& 18.47)$ with S4 in the first and second seasons respectively, producing of the other strains trees between them. These results were not due to the number of fruits per tree, but due to the fruit weight as shown in Table 4.

TABLE 1. Flowering behavior of the investigated mango strains during (2012 and 2013 seasons).

\begin{tabular}{|c|c|c|c|c|c|c|c|c|}
\hline \multirow{3}{*}{ Strains } & \multicolumn{4}{|c|}{2012 season } & \multicolumn{4}{|c|}{2013 season } \\
\hline & \multirow{2}{*}{$\begin{array}{c}\text { Date of } \\
\text { flowering }\end{array}$} & \multicolumn{2}{|c|}{ Average number of } & \multirow{2}{*}{$\begin{array}{c}\text { Malformation } \\
(\%)\end{array}$} & \multirow{2}{*}{$\begin{array}{c}\text { Date of } \\
\text { flowering }\end{array}$} & \multicolumn{2}{|c|}{ Average number of } & \multirow{2}{*}{$\begin{array}{c}\text { Malformation } \\
(\%)\end{array}$} \\
\hline & & $\begin{array}{c}\text { Panicles } \\
\text { /tree }\end{array}$ & $\begin{array}{c}\text { Malformed } \\
\text { panicles /tree }\end{array}$ & & & $\begin{array}{c}\text { Panicles } \\
\text { /tree }\end{array}$ & \begin{tabular}{|c|}
$\begin{array}{c}\text { Malformed } \\
\text { panicles /tree }\end{array}$ \\
\end{tabular} & \\
\hline S1 & $28^{\text {th }} \mathrm{Feb}$. & 196 & 4 & 2.04 & $26^{\text {th }}$ Feb. & 203 & 6 & 2.96 \\
\hline S2 & $7^{\text {th }}$ March & 231 & 8 & 3.46 & $7^{\text {th }}$ March & 237 & 11 & 4.64 \\
\hline S3 & $24^{\text {th }}$ Feb. & 107 & 10 & 7.35 & $26^{\text {th }}$ Feb. & 112 & 8 & 7.14 \\
\hline S4 & $26^{\text {th }}$ Feb. & 165 & 11 & 6.67 & $26^{\text {th }}$ Feb. & 164 & 13 & 7.93 \\
\hline S5 & $4^{\text {th }}$ April & 91 & 10 & 10.98 & $7^{\text {th }}$ April & 93 & 12 & 12.90 \\
\hline S6 & $25^{\text {th }}$ Feb. & 102 & 8 & 7.84 & $22^{\text {nd }} \mathrm{Feb}$ & 101 & 9 & 8.91 \\
\hline S7 & $8^{\text {th }}$ March & 118 & 11 & 9.32 & $8^{\text {th }}$ March & 124 & 7 & 5.65 \\
\hline S8 & $25^{\text {th }}$ April & 86 & 4 & 4.65 & $24^{\text {th }}$ April & 87 & 4 & 4.59 \\
\hline S9 & $22^{\text {nd }}$ April & 134 & 7 & 2.22 & $26^{\text {th }}$ April & 141 & 7 & 4.96 \\
\hline S10 & $27^{\text {th }}$ April & 116 & 8 & 6.89 & $28^{\text {th }}$ April & 113 & 8 & 7.08 \\
\hline S11 & $24^{\text {th }}$ April & 154 & 5 & 3.24 & $25^{\text {th }}$ April & 146 & 5 & 3.42 \\
\hline S12 & $20^{\text {th }}$ April & 126 & 6 & 4.76 & $23^{\text {rd }}$ April & 130 & 4 & 2.07 \\
\hline S13 & $23^{\text {rd }}$ April & 98 & 4 & 4.08 & $23^{\text {rd }}$ April & 87 & 4 & 4.59 \\
\hline S14 & $21^{\text {st }}$ April & 153 & 9 & 2.88 & $25^{\text {th }}$ April & 156 & 11 & 7.05 \\
\hline $\begin{array}{l}\text { L.S.D } \\
\text { at 5\% }\end{array}$ & & 10.17 & 4.01 & 4.16 & & 10.81 & 4.34 & 3.96 \\
\hline
\end{tabular}

The obtained results are in agreement with the finding of Saleh and Abd El Monem (2003), Hassan et al., (2004), Lu Ping (2005), Shinde et al., (2006), Boshra et al., (2007) and El-Agmey (2010) who found that, period from start

Egypt. J. Hort. Vol. 43, No. 1 (2016) 
blooming to harvest date in some mango strains ranged between 23 and 26 weeks and total fruit yield per tree ranged between 186.73 to $378.51 \mathrm{~kg}$.

TABLE 2. Harvest date, maturity period and yield of the investigated mango strains during (2012 and 2013 seasons).

\begin{tabular}{|c|c|c|c|c|c|c|c|c|}
\hline \multirow{2}{*}{ Strains } & \multicolumn{4}{|c|}{ 2012 season } & \multicolumn{4}{c|}{ 2013 season } \\
\cline { 2 - 9 } & $\begin{array}{c}\text { Harvest } \\
\text { Date }\end{array}$ & $\begin{array}{c}\text { Maturity } \\
\text { Period } \\
\text { (days) }\end{array}$ & $\begin{array}{c}\text { Number } \\
\text { of } \\
\text { fruit/tree }\end{array}$ & $\begin{array}{c}\text { Yield/tree } \\
\text { (Kg.) }\end{array}$ & $\begin{array}{c}\text { Harvest } \\
\text { Date }\end{array}$ & $\begin{array}{c}\text { Maturity } \\
\text { Period } \\
\text { (days) }\end{array}$ & $\begin{array}{c}\text { Number } \\
\text { of } \\
\text { fruit/tree }\end{array}$ & $\begin{array}{c}\text { Yield/tree } \\
\text { (Kg.) }\end{array}$ \\
\hline S1 & $22 / 7$ & 148 & 221 & 27.47 & $27 / 7$ & 152 & 230 & 29.72 \\
\hline S2 & $3 / 8$ & 149 & 254 & 63.02 & $1 / 8$ & 148 & 263 & 65.20 \\
\hline S3 & $26 / 7$ & 153 & 133 & 22.14 & $28 / 7$ & 151 & 138 & 23.61 \\
\hline S4 & $22 / 7$ & 147 & 179 & 20.33 & $25 / 7$ & 150 & 162 & 18.47 \\
\hline S5 & $25 / 7$ & 145 & 82 & 22.82 & $31 / 7$ & 146 & 101 & 28.39 \\
\hline S6 & $19 / 7$ & 145 & 147 & 25.96 & $18 / 7$ & 147 & 124 & 21.80 \\
\hline S7 & $4 / 8$ & 150 & 149 & 23.66 & $2 / 8$ & 148 & 150 & 23.72 \\
\hline S8 & $25 / 9$ & 149 & 74 & 47.54 & $29 / 9$ & 149 & 71 & 46.10 \\
\hline S9 & $16 / 9$ & 150 & 155 & 138.67 & $28 / 9$ & 156 & 165 & 143.31 \\
\hline S10 & $25 / 9$ & 152 & 182 & 93.29 & $28 / 9$ & 156 & 206 & 109.06 \\
\hline S11 & $22 / 9$ & 152 & 171 & 91.94 & $30 / 9$ & 153 & 187 & 100.98 \\
\hline S12 & $19 / 9$ & 153 & 136 & 62.76 & $29 / 9$ & 151 & 135 & 63.01 \\
\hline S13 & $23 / 9$ & 154 & 101 & 33.89 & $21 / 9$ & 152 & 112 & 37.85 \\
\hline S14 & $18 / 9$ & 151 & 168 & 53.34 & $22 / 9$ & 151 & 172 & 54.95 \\
\hline $\begin{array}{l}\text { L.S.D } \\
\text { at 5\% }\end{array}$ & -- & 4.02 & 6.70 & 9.12 & -- & 3.71 & 5.61 & 11.04 \\
\hline
\end{tabular}

Fruit physical characteristics

Fruit physical characteristics, i.e., peel and pulp color, peel thickness, pulp content of fiber and embryo type were shown in Table 3. Green color peel were showed with six strains (S1, S3, S5, S9, S10 and S12), while strains (S2, S8, S11 and S14) have green yellowish peel. Meanwhile strains (S6 and S13) have green with red side peel, only one strain (S4) has yellow peel and (S7) has a yellow with red side.

Regarding, peel thickness differed between thin, mediate and thick. Only strain (S3) has thin peel, but nine of strains have thick -peel (S1, 2, 5, 6, 7,8,9,10 and $\mathrm{S} 11)$, while only four once (S4, 12,13 and S14) have mediate peel.

As for pulp fruit color, eight strains (S1, 2,3,4,7,9,13 and S14) have orange pulp while, yellow pulp were noticed in the other six strains (S5, 6,8,10,11 and S12). Pulp content of fiber among high, low and free, pulp fruit of strains (5 and 10) gained the highest fiber content, while $S 2,11,12,13$ and $S 14$ were low pulp fiber, on the other hand, $S 1,3,4,6,7,8$ and $S 9$ their pulp fruit fiber free. 
Concerning embryo type, seed of three strains (S3, S4 and S10) were polyembryonic, whereas the other studied strains had monoembryonic seeds.

These results were according the finding of El Agmey, 2010 and Serry, (2010), on the other hand, Nafees (2010) mentioned that most of the seedling mango races are polyembryonic.

\section{Fruit weight and dimensions}

As shown in Table 4 fruit weight differed significantly between strains whereas the heaviest weight $(894.70 \mathrm{~g})$ and least $(124.30 \mathrm{~g})$. The fruit of strains can be arranged to three groups as follows: Above $500 \mathrm{~g}$ for S10, 11, 8 and $\mathrm{S} 9$ in an ascending order where S9 gained heaviest weight fruit. Above 200 to least of $500 \mathrm{~g}$ for S2, 5, 14, 13 and S12 in an ascending order. Least of $200 \mathrm{~g}$ for S6, 3, 7,1 and $\mathrm{S} 4$ in a descending order where S4 the lowest weight.

Regarding length, diameter and width of fruit, the data show that measurement in most cases indicate the highest measure for S9 while, the least for S4 in the two study seasons.

As for fruit shape index the revealed that, values of all strains fruits take an elongate above 1.00 values. These results confirm those of both Dutta and Dhua (2002), Boshra et al., (2007), Mamiro et al., (2007), Saeed et al., (2009) and El-Agmey (2010) who found that, the elongation of mango shape occur when fruit index was higher than 1.0.

TABLE 3. Average fruit physical characteristics of the investigated mango strains during ( 2012 and 2013 seasons).

\begin{tabular}{|c|c|c|c|c|c|}
\hline Strains & Peel colour & Peel thickness & Pulp colour & $\begin{array}{c}\text { Pulp content } \\
\text { of fiber }\end{array}$ & $\begin{array}{c}\text { Embryo } \\
\text { type }\end{array}$ \\
\hline S1 & Green & thick & orange & fiber free & mono \\
\hline S2 & Green Yellowish & thick & orange & fiber low & mono \\
\hline S3 & Green & Thin & orange & fiber free & Poly \\
\hline S4 & Yellow & mediate & orange & fiber free & Poly \\
\hline S5 & Green & thick & Yellow & fiber high & Mono \\
\hline S6 & $\begin{array}{c}\text { Green with red } \\
\text { side }\end{array}$ & thick & Yellow & fiber free & Mono \\
\hline S7 & $\begin{array}{c}\text { Yellow with red } \\
\text { side }\end{array}$ & thick & orange & fiber free & Mono \\
\hline S8 & Green Yellowish & thick & Yellow & fiber free & Mono \\
\hline S9 & Green & thick & orange & fiber free & Mono \\
\hline S10 & Green & thick & Yellow & fiber high & poly \\
\hline S11 & Green Yellowish & thick & Yellow & fiber low & Mono \\
\hline S12 & Green & mediate & Yellow & fiber low & Mono \\
\hline S13 & $\begin{array}{c}\text { Green with red } \\
\text { side }\end{array}$ & mediate & orange & fiber low & Mono \\
\hline S14 & Green Yellowish & mediate & orange & fiber low & mono \\
\hline
\end{tabular}

Egypt. J. Hort. Vol. 43, No. 1 (2016) 
EVALUATION OF SOME MANGO STRAINS UNDER ISMAILIA ...

TABLE 4. Fruit weight, dimensions and shape index of the investigated mango strains during (2012 and 2013 seasons).

\begin{tabular}{|c|c|c|c|c|c|c|c|c|c|c|}
\hline \multirow[b]{2}{*}{ Strains } & \multicolumn{5}{|c|}{2012 season } & \multicolumn{5}{|c|}{2013 season } \\
\hline & $\begin{array}{c}\text { Fruit } \\
\text { weight } \\
\text { (g) }\end{array}$ & \begin{tabular}{|c|} 
Fruit \\
Length \\
(cm)
\end{tabular} & \begin{tabular}{|c|}
$\begin{array}{c}\text { Fruit } \\
\text { diameter } \\
(\mathrm{cm})\end{array}$ \\
\end{tabular} & $\begin{array}{l}\text { Fruit } \\
\text { width } \\
\text { (cm) }\end{array}$ & \begin{tabular}{|l|} 
Fruit \\
shape \\
index
\end{tabular} & \begin{tabular}{|c|}
$\begin{array}{c}\text { Fruit } \\
\text { weight } \\
\text { (g) }\end{array}$ \\
\end{tabular} & \begin{tabular}{|c|} 
Fruit \\
Length \\
(cm)
\end{tabular} & \begin{tabular}{|c|}
$\begin{array}{c}\text { Fruit } \\
\text { diameter } \\
(\mathbf{c m})\end{array}$ \\
\end{tabular} & \begin{tabular}{|c|}
$\begin{array}{c}\text { Fruit } \\
\text { width } \\
(\mathrm{cm})\end{array}$ \\
\end{tabular} & $\begin{array}{l}\text { Fruit } \\
\text { shape } \\
\text { index }\end{array}$ \\
\hline S1 & 124.3 & 9.8 & 7.6 & 6.3 & 1.29 & 129.2 & 9.8 & 7.7 & 6.5 & 1.27 \\
\hline S2 & 248.1 & 11.4 & 10.1 & 9.2 & 1.13 & 247.9 & 11.5 & 9.9 & 9.4 & 1.16 \\
\hline S3 & 166.5 & 12.0 & 7.8 & 6.9 & 1.54 & 171.1 & 12.1 & 7.7 & 6.9 & 1.57 \\
\hline S4 & 113.6 & 11.3 & 6.4 & 5.7 & 1.76 & 114.0 & 11.3 & 6.5 & 5.6 & 1.74 \\
\hline S5 & 278.3 & 12.7 & 8.9 & 8.2 & 1.43 & 281.1 & 12.8 & 8.8 & 8.3 & 1.45 \\
\hline S6 & 176.6 & 12.1 & 7.4 & 6.5 & 1.64 & 175.8 & 12.0 & 7.4 & 6.6 & 1.62 \\
\hline S7 & 158.8 & 11.4 & 7.8 & 6.3 & 1.46 & 158.1 & 11.3 & 7.9 & 6.3 & 1.43 \\
\hline S8 & 642.4 & 14.3 & 9.7 & 8.9 & 1.47 & \begin{tabular}{|l|}
649.3 \\
\end{tabular} & 14.5 & 9.6 & 9.0 & 1.51 \\
\hline S9 & 894.7 & 15.1 & 11.4 & 10.1 & 1.32 & 868.6 & 15.0 & 11.2 & 10.2 & 1.34 \\
\hline S10 & 512.6 & 12.8 & 9.3 & 8.2 & 1.38 & 529.4 & 12.7 & 9.4 & 8.4 & 1.35 \\
\hline S11 & 537.7 & 13.1 & 9.6 & 8.8 & 1.36 & 540.0 & 13.2 & 9.6 & 8.7 & 1.38 \\
\hline S12 & 461.5 & 17.4 & 8.9 & 6.5 & 1.96 & 466.7 & 16.9 & 9.1 & 6.4 & 1.86 \\
\hline S13 & 335.6 & 9.7 & 8.3 & 7.6 & 1.17 & \begin{tabular}{|l|}
338.0 \\
\end{tabular} & 9.6 & 8.4 & 7.5 & 1.14 \\
\hline S14 & 317.5 & 9.1 & 8.0 & 7.2 & 1.14 & \begin{tabular}{|l|}
319.5 \\
\end{tabular} & 9.2 & 8.0 & 7.1 & 1.15 \\
\hline $\begin{array}{l}\text { L.S.D } \\
\text { at 5\% }\end{array}$ & 6.9 & 1.98 & 1.03 & 0.65 & 0.18 & 8.3 & 1.71 & 1.40 & 0.84 & 0.16 \\
\hline
\end{tabular}

Seed, peel and pulp percentage

Tabulated data in Table 5 clearly showed that, percentage of seed in relation to fruit weight of tested strains was significantly differed in the two seasons. In this concern, the lowest percentage of seed weight was in fruit of S9, 12, 8 and $\mathrm{S} 11$, respectively in both seasons. Where seed weight for S9 recorded $(5.81 \&$ $5.93 \%)$, while S11 (8.32\& $8.59 \%)$, however, the other strains their percentage seed to fruit weight ranged from 1.01 to $39.03 \%$ during two studied seasons.

As for percentage of peel in relation to fruit weight, the least percentage of peel weight were in fruit of S8, 12, 9 and S10 respectively in both seasons, where, peel weight of S8 gained (10.89\& 11.04 \%), while S10 (15.21 \& 15.34 $\%$ ), on the other hand, the other strains their percentage peel to fruit weight ranged from 18.62 to $43.01 \%$ during two study seasons.

Pulp percentage in fruit of tested strains significantly differed in two study seasons. the highest pulp percentage for (S8, 12, 9, 11 and S10) through first and second seasons in a descending order, meanwhile, S8 achieved (81.45 and $81.38 \%$ ) whereas, remained strains $\mathrm{S} 1,2,3,4,5,6,7,13$ and $\mathrm{S} 14$ recorded least values in this concern during two examined seasons.

These results are in line with the finding of Thakur et al. (2000), Hammam et al., (2001), El-Wakeel et al., (2006), Scholefield et al. (2006), Reddy and Reddy (2009), El-Agmey (2010) Hagage (2010) and Serry (2010) who noticed 
that, percentage of seed, peel and pulp in relation to fruit weight, differed between varieties and strains.

\section{Fruit chemical constituents}

Total soluble solid (T.S.S.) Brix in juice strains fruit during 2012 and 2013 seasons was showed in Table 5. In point of fact the total soluble solids of mango varieties fruits above 15 values, it is worthy there are some tested strains were recorded similar values in this respect through both seasons, can be mentioned in a descending order as follows: S13, 4, 10, 14, 8, 12, 9, 3, 11 and S1.

As for acidity ranged from 1.01 to 2.40 in all strains fruits during the two seasons, whereas, the least values $(1.01 \& 1.01)$ for $\mathrm{S} 1$ while, the highest $(2.40 \&$ 2.30) for S10 and S14. Concerning TSS/acid ratio the highest values belonged strains $\mathrm{S} 1,4$, and S9 in two study seasons.

The obtained results are harmony with those of Mitra et al. (2001), Tawfik (2003), Chanana et al., (2005), El-Wakeel et al., (2006), Mauco et al., (2009), Hagage (2010) and Serry (2010) who noticed that, total soluble solids and acidity varied among the different cultivars and races.

TABLE 5. Seed, peel, pulp weight percentage and T.S.S., acidity and TSS/acid ratio of mango strains fruits during (2012 and 2013 seasons).

\begin{tabular}{|c|c|c|c|c|c|c|c|c|c|c|c|c|}
\hline \multirow[b]{3}{*}{ 薦 } & \multicolumn{6}{|c|}{2012 season } & \multicolumn{6}{|c|}{2013 season } \\
\hline & \multicolumn{3}{|c|}{$(\%)$} & \multirow[b]{2}{*}{$\begin{array}{l}\dot{\leftrightarrow} \\
\dot{\leftrightarrow} \\
\dot{\theta}\end{array}$} & \multirow[b]{2}{*}{$\stackrel{3}{:}$} & \multirow[b]{2}{*}{ 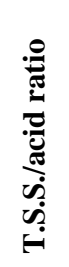 } & \multicolumn{3}{|c|}{$(\%)$} & \multirow[b]{2}{*}{$\stackrel{\dot{\varphi}}{\dot{\leftrightarrow \varphi}}$} & \multirow[b]{2}{*}{ 莺 } & \multirow[b]{2}{*}{ 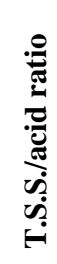 } \\
\hline & 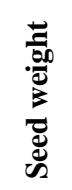 & 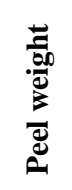 & 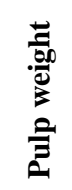 & & & & 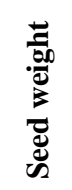 & 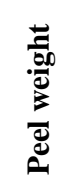 & 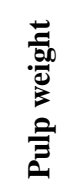 & & & \\
\hline S1 & 39.03 & 26.42 & 34.55 & 16.00 & 1.01 & 15.84 & 38.91 & 26.83 & 34.86 & 16.20 & 1.01 & 16.04 \\
\hline S2 & 22.39 & 41.30 & 36.31 & 14.00 & 2.10 & 6.67 & 24.63 & 42.18 & 33.19 & 14.00 & 2.10 & 6.67 \\
\hline S3 & 21.70 & 35.20 & 43.01 & 17.20 & 1.31 & 13.23 & 21.84 & 37.10 & 41.06 & 17.40 & 1.40 & 12.14 \\
\hline S4 & 35.79 & 32.73 & 31.48 & 21.00 & 1.40 & 15.00 & 35.63 & 33.42 & 30.95 & 21.00 & 1.40 & 15.00 \\
\hline S5 & 34.81 & 42.63 & 22.56 & 10.20 & 1.50 & 6.80 & 34.77 & 43.01 & 22.22 & 10.30 & 1.60 & 6.43 \\
\hline S6 & 29.70 & 34.80 & 25.50 & 13.00 & 1.10 & 11.81 & 30.19 & 36.55 & 33.26 & 13.10 & 1.20 & 10.91 \\
\hline S7 & 27.99 & 34.41 & 37.60 & 14.00 & 1.30 & 10.76 & 27.86 & 36.02 & 36.12 & 14.20 & 1.40 & 10.14 \\
\hline S8 & 7.66 & 10.89 & 81.45 & 19.00 & 2.01 & 9.45 & 7.58 & 11.04 & 81.38 & 19.10 & 2.01 & 9.50 \\
\hline S9 & 5.81 & 15.01 & 79.18 & 18.00 & 1.20 & 15.00 & 5.93 & 15.22 & 77.85 & 18.00 & 1.30 & 13.84 \\
\hline S10 & 11.12 & 15.21 & 73.67 & 20.00 & 2.40 & 8.33 & 11.39 & 15.34 & 72.65 & 20.00 & 2.30 & 8.69 \\
\hline S11 & 8.32 & 18.04 & 73.64 & 17.00 & 1.40 & 12.14 & 8.59 & 18.62 & 72.84 & 17.10 & 1.40 & 12.21 \\
\hline S12 & 6.70 & 12.28 & 81.02 & 19.00 & 1.80 & 10.56 & 6.68 & 13.56 & 79.76 & 19.10 & 1.70 & 11.23 \\
\hline S13 & 11.01 & 31.28 & 51.71 & 23.00 & 2.10 & 10.95 & 11.37 & 31.76 & 56.87 & 23.00 & 2.10 & 10.95 \\
\hline S14 & 14.04 & 31.12 & 54.84 & 19.20 & 2.40 & 8.00 & 5.21 & 31.08 & 52.71 & 19.20 & 2.30 & 8.34 \\
\hline $\begin{array}{c}\text { L.S.D at } \\
\mathbf{5 \%}\end{array}$ & 4.12 & 6.07 & 10.13 & 0.86 & 0.05 & 4.51 & 6.14 & 8.02 & 9.73 & 0.91 & 0.07 & 4.87 \\
\hline
\end{tabular}

Egypt. J. Hort. Vol. 43, No. 1 (2016) 


\section{References}

Abourrya, M.S, Kassiam, N.E., El-Sheikh, M.H. and Rakha, A.M. (2011) Fruit physical and chemical characteristics at maturity stage of Tommy Atkins, Keitt and Kent mango cultivars grown under Nubariye condition. J. Amer.Sci. 7(3:425 -433)

Aononymous, (2007) Food and Agricultural Organization of United Nations Economic and Social Dept. The statistical Dev. (http://Fao stat. Fao. org/ site/ 567).

A.O.A.C. (1985) Official Method of Analysis of Association of Official Analysis Chemist, Washington. D.C. U.S.A.

Boshra, E., Aboul-Soad A. S. and Said, A.G. (2007) Selection of some mango grown in Assuit .Egypt J. Plant Breed, 11 (1), 223-234.

Chanana, Y.R., Josan, J.S. and Arora, P.K. (2005) Evaluation of some mango cultivars under North India conditions. In Malik A.U.M.A. Pervez and K.Ziaf (Eds). Proceedings of international conference mango and Date palm: culture and Export. Institute of Hort. Sci. Univ. of Agric Faisalubad, Pakiston, pp. 35-40.

Devilliers, F.A. (1998) The cultivation of mango Institute of Tropical and subtropical fruits. pp 28-30.

Dutta, P. and Dhua, R.S. (2002) Improvement on fruit quality of Himsagar mango through application of zinc, iron and manganese, Hort. J., 15, 1-9.

El-Agmey, M.K.F. (2010) Evaluation of some mango seedling strains under Giza Governorate conditions. Egypt. J. Appl. Sci., 26 (12B) 353-365.

El-Kosary, S., El-Shenawy, I.E. and Radwan, S.I. (2011) Effect of microelements, amino and humic acids on growth, flowering and fruiting of some mango cultivar. J. Hort. Sci. Ornam Plants, 3 (2), 152-161.

El-Wakeel, H.F., Rashid, M.M. and Bo-Rashid, R.K. (2006) Evaluation of some mango cultivars under eastern coast condition of United Arab Emirates. Annals Agric. Sci., 1, 179-190.

Hagage, W.M. (2010) Mango diseases in Egypt. Agric. Biol. J. N. Amer., 1 (3), 285-289.

Hammam, M.S., Sabour, A.M. and Sanaa, E. (2001) Trial for alleviating inflorescence malformation in Taimoar and Mabrouk mango trees. Ann. Agric. Sci., Cairo, 46, 753766.

Hassan, A.M., Gihan, M.A. and Sanaa, E. (2004) Maturation and heat units of some mango cultivars. Egypt. J. Appl. Sci.,19 (5B), 553-571.

Jana, A. and Sharangi, A.B. (1998) Fruit drop in different varieties of mango. Environ. Ecology., 16 (1), 127-131.

Lu-Ping (2005) Use of Ethrel to eliminate late flushing and promote flowering in mango. Institute of Hort. Sci., Univ. Agric. Faisalabad Pakistan. pp. 34-39. 
Mamiro, P.E., Chovc, B., Kinabo, J., George, V. and Mtebe, K. (2007) Physical and Chemical characteristics of offing ripened mango (Mangifera indica L.) fruit (Dodo). African J. Bio. Techn., 6, 2477-2483.

Mitra, S., Kunda, S. and Mitra, S.K. (2001) Chemical composition of some varieties and Hybrids of mango. Environ. and Ecology, 19 (2), 487-488.

Mouco, M.A., Lima, M.A., Desilva, A.L., Dasantos, S.C. and Rodrigues, F.M. (2009) Amino acids on mango yield and fruit quality at sub Medio Sao Francisco, Region, Brazil. Acta. Hort., 820, 437-442.

Nafees, M., Anwar, R., Jameel, M. and Aslam, M.N. (2010) Flushing pattern of mango (Mangifera indica L.) cultivar in response to pruning of panicles and its effect on carry over effect of floral malformation. Pak. J. Agric. Sci., 47 (1), 13-18.

Oosthyse, S.A. (1993) Mango tree spacing trends and options for yield improvement with special reference to south Africa, J. S. Assoc. Hort. Sci., 3 (2), 92-96.

Reddy, E.V. and Reddy, O.V. (2009) Production, optimization and characterization of vine from mango (Mangifera indica L.), Natural product Radiance, 8 (8), 426-435.

Saeed, A., Mahamoud, S., Nasir, M. and Sultan, M. (2009) Sensory evaluation of mango (Mangifira indica L.) grown in different Regions of Pakistan. Pak. J. Bot., 41 (6) 2821-2829.

Said, G.A. and El-Masry, H.M. (1992) Evaluation of two new introduced mango cvs. under .Giza, Egypt conditions .Ann. Agric. Sci. Moshtohor, 30 (1), 447-463.

Saleh, M.M. and Abd-El-Monam, E. (2003) Improving the productivity of Fgri "Kalan" mango trees grown under sandy soil conditions using potassium, boron and sucrose as foliar spry. Ann. Agric. Sci., Cairo, 48, 747-756.

Sayed, A.L., Iqbal, Z. and Mohamed, H. (2009) The extent of micro minerals in healthy and malformed organs of mango. Pak. J. Bot., 41, 2817-2820.

Scholefield, P.B., Oag, D.R. and Sedgley, M. (2006) The relationship between vegetative and reproductive development in mango in northern Australia. Auster. $J$. Agric., Res., 37 (4), 428-433.

Serry, K.H. (2010) Evaluation of some mango strains growing under Ismailia conditions. Res. J. Agric. Biol. Sci., 6 (6), 840-845.

Shafqat, S., Asad, M. and Khan, S.M. (2012) Diseased plants as a source of dissemination of mango sudden death disease in healthy mango plants. Pak. J. Phytopathol., 24 (1), 21-25.

Shinde, A.K., Patil, B.P., Pajari, K.H., Jadhav, B.B., Chandelkar, A. B. and Kandal kar, M.P. (2006) Investigation on the control of fruit drop in Alphonso mango. Indian J. Plant Physiol., 11, 93-99.

Singh, H. and Chadha, K.L. (1981) Evaluation of some mango cultivars on the basis of their biochemical composition, J. Hort., 38, 70-73.

Egypt. J. Hort. Vol. 43, No. 1 (2016) 
Steel, R.G. and Torrie, J.H. (1980) "Principles and Procedure of Static's", McCrae Hill book Company, 633p.

Tawfik. E.S. (2003) Evaluation of some export mango cultivars grown in Egypt. Ph.D. Thesis, Fac. Agric., Assiut Univ., Egypt, 187p.

Thakur, A.S., Vaishampayan, S.M. and Shukla, A. (2000) Effect of varieties, nutrients and direction on the incidence of floral and vegetative malformation in grafted mango. Crop Res. (Hisar), 20, 494-499.

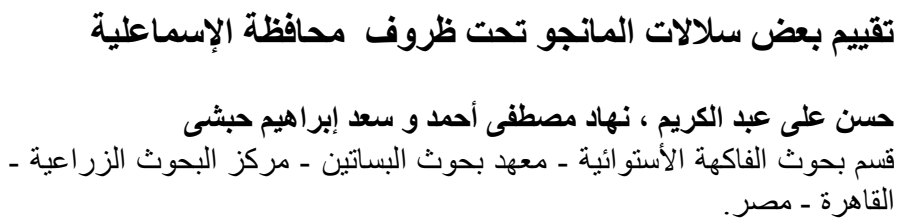

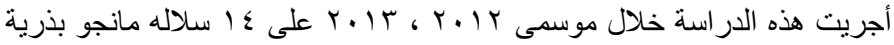

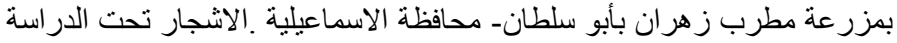

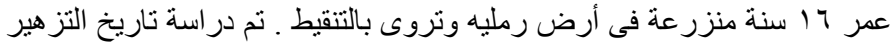

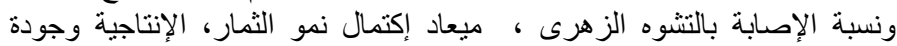

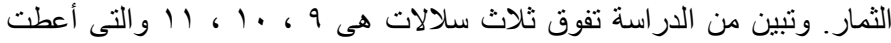

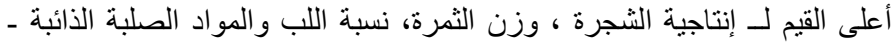

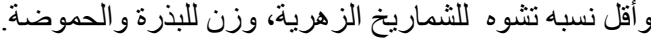

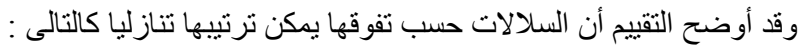

9، 11 ، ، ، 1 وتعد سلالات مميزة وكأصناف جديدة للمانجو. 